\title{
Asymmetric Location of the Septum in Morphologically Altered Cells of the Fission Yeast Schizosaccharomyces pombe
}

\author{
By MACHIKO MIYATA, $1,3 *+$ HISAO MIYATA 2,3 AND \\ BYRON F. JOHNSON ${ }^{3}$ \\ ${ }^{1}$ Gifu Pharmaceutical University, 6-1, Mitahora-higashi 5 chome, Gifu 502, Japan \\ 2 Department of Biology, Faculty of Science, Nagoya University, Chikusa-ku, Nagoya 464, Japan \\ ${ }^{3}$ Division of Biological Sciences, National Research Council of Canada, Ottawa, \\ Ontario K1A 0R6, Canada
}

(Received 2 July 1985 ; revised 8 November 1985)

\begin{abstract}
Cells of the fission yeast Schizosaccharomyces pombe, normally sausage-shaped, changed to a round-bottomed flask (RBF)-like morphology during growth in the presence of aculeacin $A$ (Acu), an antifungal antibiotic. The volume of RBF-like cells was comparable to that of the control cells. After being transferred to normal conditions (without Acu at $25^{\circ} \mathrm{C}$ ), the RBF-like cells continued to grow at the cylindrical and/or spherical end(s) and then the septum at the subsequent division of the cells was formed without exception at the boundary plane between the spheroidal and the cylindrical region; it is at this boundary that the nucleus was located before mitosis. Hence the RBF-like cell divided into a spheroidal and a cylindrical sib at the first cell division. At the end of the second cell cycle, the spheroidal and the cylindrical progeny divided into two spheroidal and two cylindrical sibs respectively. The values of the mean length (long/short) and volume (big/small) ratios of paired sibs were larger in order of (a) cylindrical normal, with both mean ratios 1.06; (b) cylindrical control; $(c)$ cylindrical progeny of RBF-like cell; $(d)$ spheroidal progeny of RBF-like cell; and $(e)$ RBF-like cell, whose mean length ratio was 1.25 but whose mean volume ratio was 1.94 . That is, the more the morphology deviated from the cylindrical form, the greater was the degree of asymmetry. There was no rule relating the biases to the growth pole in these asymmetries.
\end{abstract}

\section{INTRODUCTION}

Cell division of the sausage-shaped fission yeast Schizosaccharomyces pombe is considered to be typical binary fission. The mechanism for the positioning of the septum site, however, is unknown. Using wild-type strain 132 and its germinating spores, Johnson et al. (1979) pointed out that, although the volumes of the resultant sibs were equal, the septum was sited asymmetrically $(10 \%)$ by a length parameter.

Aculeacin A (Acu) is an antifungal antibiotic produced by Aspergillus aculeatus (Mizuno et al., 1977), which causes cell death by lysis through inhibition of the synthesis of cell wall glucan at the bud-tip of Saccharomyces cerevisiae (Mizoguchi et al., 1977). Yamaguchi et al. (1982) demonstrated that the activity of $\beta$-glucan synthase was inhibited by Acu in studies with cellfree extracts of Candida albicans and Saccharomyces cerevisiae.

Our earlier studies (Miyata et al., 1980) showed that Acu caused lysis of the growing fission yeast $S$. pombe at the end of the cell and in the septal region, the regions of active wall synthesis. Later (Miyata et al., 1985), we reported that cells of a temperature-sensitive mutant of $S$. pombe ( $\left.c d c 10-121 \mathrm{~h}^{-}\right)$, grown in the presence of low doses of Acu, formed spherical walls in which wall

† Offprint requests should be sent to the Ottawa address.

Abbreciations: Acu, aculeacin A: RBF-like, round-bottomed flask-like. 

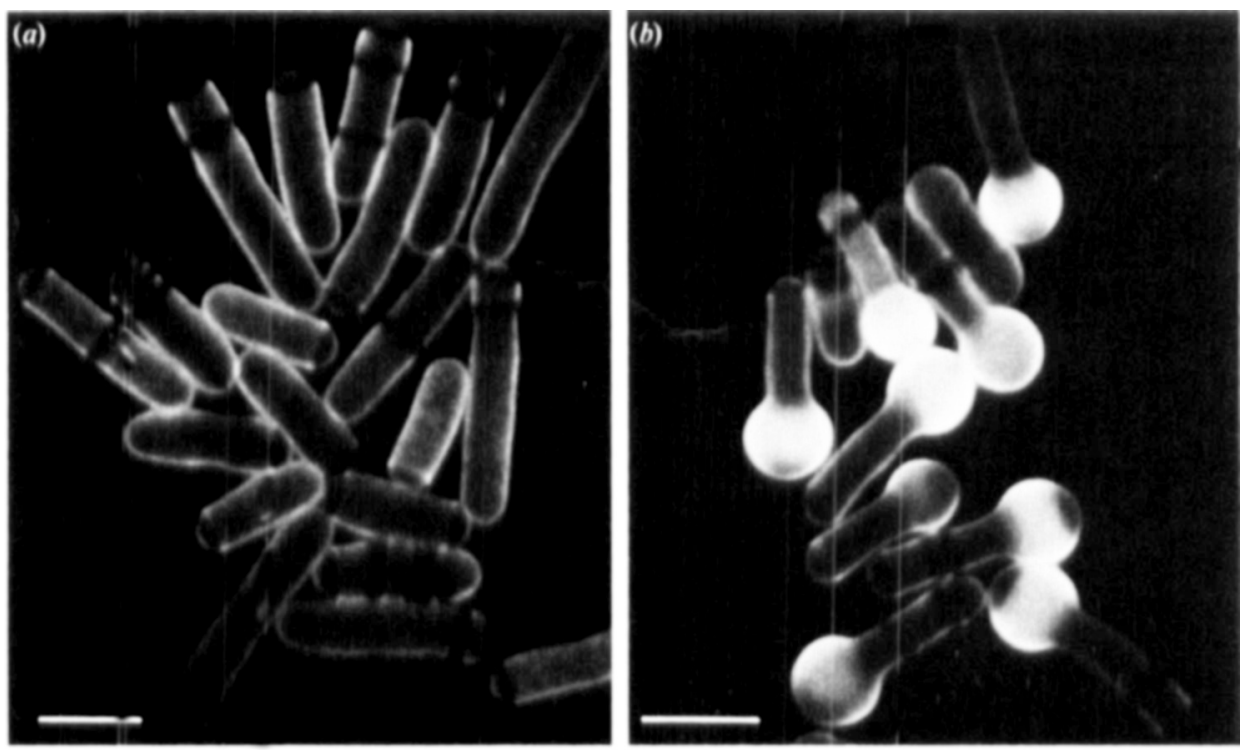

Fig. I. Cells of $S$. pombe $c d c 10-121 \mathrm{~h}^{-}$cultured for $6 \mathrm{~h}$ at $35^{\circ} \mathrm{C}$ and stained with Calcofluor. (a) No addition (control); (b) addition of Acu after $3 \mathrm{~h}$ incubation at $35^{\circ} \mathrm{C}$. Note growth at only one end. Bars, $10 \mu \mathrm{m}$.

polysaccharides contained a small proportion of $\beta$-glucan and a large proportion of $\alpha$-glucan compared with the cylindrical control. The experimental cells were altered morphologically into 'round-bottomed flask' (RBF)-like forms. When the RBF-like cells were transferred into fresh medium without Acu at the permissive temperature, the cells continued to grow and then two synchronous divisions followed.

We have now examined the positions of the septum sites and report here on the relationship between the extent of asymmetry of cell division and the morphological alterations of cells.

\section{METHODS}

Yeast strain. Schizosaccharomyces pombe $c d c 10-121 \mathrm{~h}^{-1}$, a temperature-sensitive mutant of wild-type strain $972 \mathrm{~h}^{-}$(Nurse et al., 1976), was used as previously described (Miyata et al., 1985). DNA synthesis of the mutant is rapidly inhibited on shifting from $25^{\circ} \mathrm{C}$ to $35^{\circ} \mathrm{C}$, but cells already in $\mathrm{S}$ and $\mathrm{G} 2$ divide once, generating a plateau of cell number after about $3 \mathrm{~h}$. After this the uninucleate cells grow only in cell length.

Chemicals. Stock solutions of aculeacin A were prepared in methanol as described by Miyata et al. (1980).

Medium and culture conditions. To obtain RBF-like cells, the same minimal medium (EMM 2; Mitchison, 1970) and culture conditions were used as described by Miyata $e t$ al. (1985). The $16 \mathrm{~h}$-grown cells, cultured at $25^{\circ} \mathrm{C}$, were used to inoculate fresh EMM 2 at a density of $8.5 \times 10^{\circ}$ cells $\mathrm{ml}^{-1}$. This culture was incubated at $35^{\circ} \mathrm{C}$ for $3 \mathrm{~h}$ at which time the cell density was about $1.5 \times 10^{7}$ cells $\mathrm{ml}^{-1}$. Acu was added to a final concentration of $1 \mu \mathrm{g} \mathrm{ml}^{-1}$ and incubation was continued at the same temperature for $3 \mathrm{~h}$. Control cells were treated identically except that Acu was not added to the medium after $3 \mathrm{~h}$ at $35^{\circ} \mathrm{C}$. Because the mutant cells at the restrictive temperature grow only at one (primary pole) end (Fig. $1 \mathrm{a}$ ), the cells grown in the presence of Acu exhibited morphological alterations as RBF-like shapes (Fig. I b). The RBF-like cells were then centrifuged, transferred into fresh medium in the absence of Acu at a cell density of 1.5-3.0 $\times 10^{6}$ cells $\mathrm{ml}^{-1}$, and incubated at $25^{\circ} \mathrm{C}$. The RBF-like cells under this condition continued to grow with four different types of growth. There was cylindrical growth (1) at both (primary and secondary poles) ends or (2) at the end of the spherical (primary pole) region or (3) at the end (secondary pole) of the cylindrical region, or (4) spherical growth at the spherical region. The first type of growth was the most common (Fig. 2). The cells formed their first septa synchronously after about $3.5 \mathrm{~h}$ and the second after about $6 \mathrm{~h}$ (Fig. 2). The peak of septations of the Acu-treated cells was slightly later (about 15 to $30 \mathrm{~min}$ ) than that of the controls. Thus, this is a form of induction synchronous culture. The division index (or degree of synchrony, the percentage of cells with visible septa; Miyata \& Miyata, 1978) was about $75 \%$ and $30 \%$ at the first and second septations respectively.

Staining. For the staining of nuclei, cells fixed with $4 \%(\mathrm{v} / \mathrm{v})$ glutaraldehyde in $0 \cdot 1 \mathrm{M}$-potassium phosphate buffer ( $\mathrm{pH} 6.8$ ) were stained with Giemsa after RNAase digestion, according to a modification of the method of Hartwell (1970). 


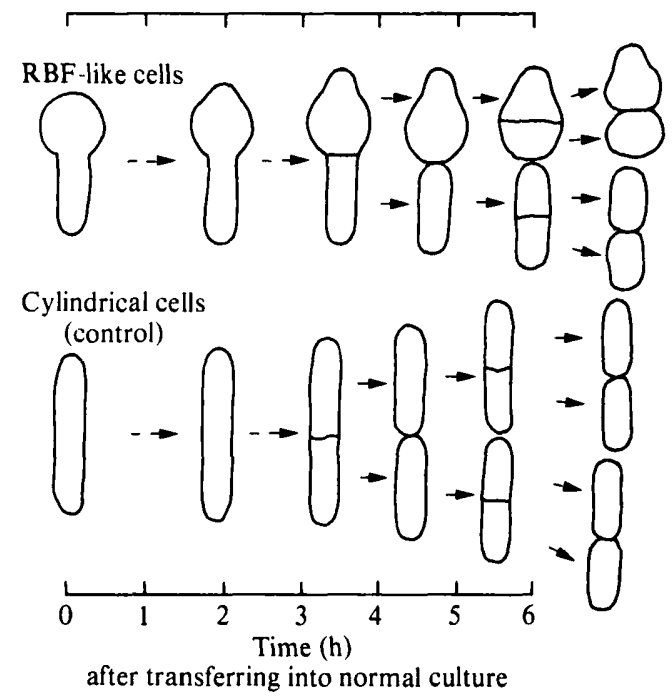

Fig. 2. Diagrammatic representation of cell divisions in RBF-like cells compared with cylindrical (control) cells. The progeny of the RBF-like cells are from left to right: the RBF-like cell divides to generate a spheroidal sib and a cylindrical sib; these cells themselves divide to generate two spheroidal and two cylindrical sibs respectively. Bipolar growth is shown, the most common type of recovery growth (Methods).

For determination of the primary and secondary poles, living cells were stained with Calcofluor and examined by fluorescence microscopy (Johnson et al., 1979).

Measurements of cell lengths and calculations of cell volumes. Photographs were taken with an Olympus model EHS microscope, or a Reichert Zetopan microscope equipped for incident light fluorescence and with Olympus objective lenses. These were magnified about 1500 times and traced on $1 \mathrm{~mm}$ section papers. Length was measured with a Vernier hand caliper or NEC PC-8875 Personal Tablet (digitizer; Nippon Electric Co.) on the traced, outlined pictures. Measuring by the Personal Tablet was done semiautomatically: the measurer pinpointed the boundaries of the cells with the electronic pen, an NEC PC-8001 mk II desk computer transformed the received coordinates into length and width measurements and then finally calculated real volumes and ratios of paired sibs. The volumes $\left(\mu \mathrm{m}^{3}\right)$ were calculated as $\mathrm{V}=\alpha \sum \pi(d / 2)^{2} l$; where $d$ is a cell diameter sectioned every $1 \mathrm{~mm}$ perpendicularly to the long axis of the cell traced out on the $1 \mathrm{~mm}$ section paper, $l$ is thickness of the section (i.e. $1 \mathrm{~mm}$ ), and $\alpha$ is a magnification constant. The number of septa-bearing cells measured was $50-120$ per sample. The spheroidal regions of the RBF-like cells or the spheroidal cells might have been slightly deformed by pressure from the coverglass, but if so the resultant errors were nevertheless small.

In this paper, the word 'spheroidal' includes cells with spherical, lemon-like or pear-like morphology (see Fig. $3 b, f)$.

\section{RESULTS}

Bright-field photomicrographs were used in the first experiment and fluorescence photomicrographs of Calcofluor-stained cells (for fission-scar distribution analysis) were used in the second (Fig. $3 e$ and $f$ ). The results obtained by the two methods (Table 1) agreed when the length ratios of the long sib vs the short sib and the volume ratios of the big sib vs the small sib were compared.

RBF-like morphology was the result of spherical growth at a pole of Acu-treated cells, in contrast with normal elongation growth of controls. The mean cell length of the RBF-like cells at septation was $18 \mu \mathrm{m}$ compared to $24 \mu \mathrm{m}$ for controls (Table 1 ). However, the mean cell volume of RBF-like cells at septation was $311 \mu \mathrm{m}^{3}$, about the same as the $300 \mu \mathrm{m}^{3}$ of control cells, although for both, the volumes were distributed over the broad range of 160 to $500 \mu \mathrm{m}^{3}$ (Table 1 ; Fig. 4). The near equality of cell volumes suggests that the spherical growth occurred to the same extent as cylindrical growth although the cells were markedly altered in morphology. Other evidence supporting this suggestion of growth equality is that the altered cells proliferated with 

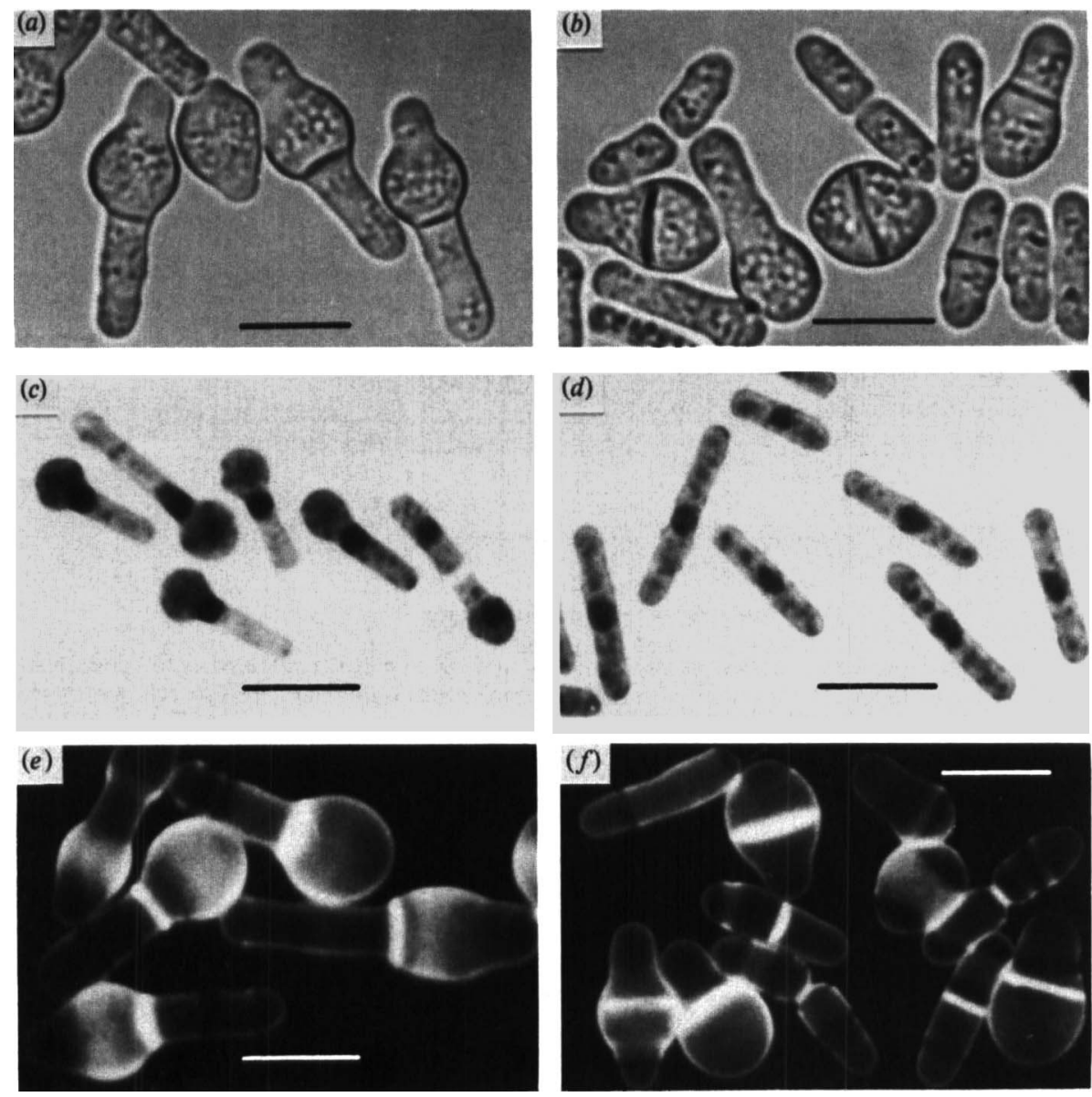

Fig. 3. Bright-field micrographs of RBF-like cells with septum (a) at $3.5 \mathrm{~h} \mathrm{(Fig.} \mathrm{2)} \mathrm{and} \mathrm{of} \mathrm{septate}$ cylindrical and spheroidal progenies of RBF-like cells $(b)$ at $6 \mathrm{~h}$ (Fig. 2); Giemsa-stained RBF-like cells $(c)$ and controls $(d)$ at zero time (Fig. 2); fluorescence micrographs of RBF-like cells with septum (e) at $3.5 \mathrm{~h}$ (Fig. 2) and of septate cylindrical and spheroidal progenies of RBF-like cells ( $f$ ) at $6 \mathrm{~h}$ (Fig. 2); bars, $10 \mu \mathrm{m}$. Note that in $(e)$ the four cell types of recovery growth can be seen as described in Methods.

about the same generation times ( $3-3.5 \mathrm{~h}$ to the first cell division and $2-2.5 \mathrm{~h}$ to the second) as the controls in the recovery system (see Fig. 2).

In fixed preparations, whether stained for light microscopy (Fig. 3c) or prepared for electron microscopy (Miyata et al., 1985), the interphase nuclei were located at the boundary between the spheroidal and the cylindrical regions, where the septa later formed without exception (Fig. $3 a$, $e$ ). Then, at the first cell division, the RBF-like cells divided into spheroidal and cylindrical sibs (Fig. 2). At the end of the second cell cycle, the spheroidal cell divided into two spheroidal sibs and the cylindrical cell divided into two cylindrical sibs (Figs 2 and $3 b, f$ ).

Cells in all morphological classes showed more or less asymmetrical cell division in both length and volume. We found that the more irregular the cell morphology, the more asymmetrically placed was the new septum. Fig. 5 shows the distributions of ratios of length and volume of paired sibs in various morphological classes for the cells of expt $I$ in Table 1 plus the cylindrical normal cells from expt II. The mean length and volume ratios are summarized in Table $1 \mathrm{in}$ which the asymmetry of septum placement is indicated when the mean ratios of Lo/Sh or $\mathrm{Bi} / \mathrm{Sm}$ of paired sibs exceeds 1.00 (Lo/Sh means length of long sib per length of short sib; $\mathrm{Bi} / \mathrm{Sm}$ means volume of big sib per volume of small sib). Both length and volume ratios increased in the order of $(a)$ cylindrical normal, $(b)$ cylindrical control, $(c)$ cylindrical progeny of RBF-like 


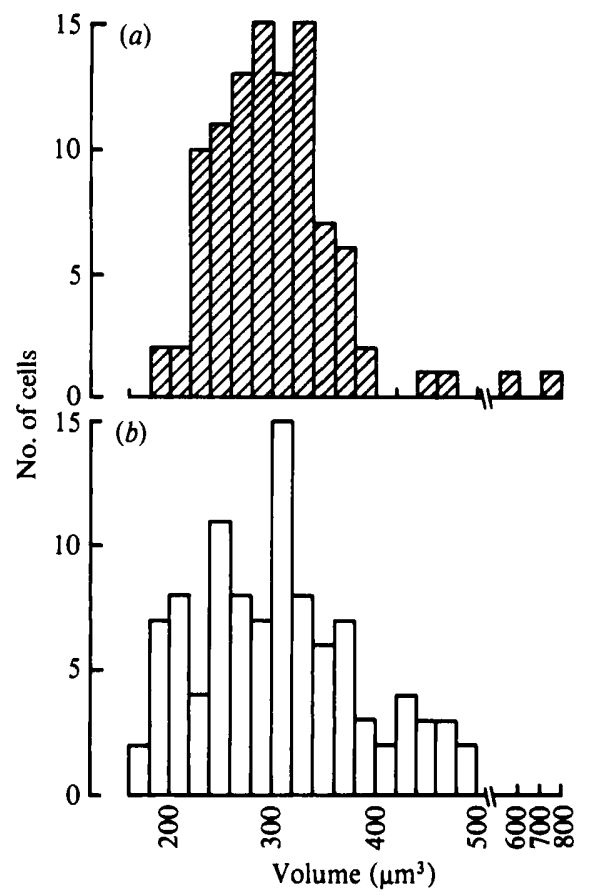

Fig. 4. Volume distributions of RBF-like cells and cylindrical control cells at septation ( $3.5 \mathrm{~h}$ in Fig. 2). (a) Cylindrical control cells, the mean volume was $300 \mu \mathrm{m}^{3}$; (b) RBF-like cells, the mean volume was $311 \mu \mathrm{m}^{3}$.

Table 1. Mean ratios of length and volume of paired sibs in various morphological classes

Note that ratios of $\mathrm{Lo} / \mathrm{Sh}$ and $\mathrm{Bi} / \mathrm{Sm}$ show 'asymmetry' of septum position in a cell and that those of $\mathrm{P} / \mathrm{S}$ show 'bias' of septum position to the primary or secondary pole (see text). Results are means $( \pm S D)$ of 50-120 cells.

\begin{tabular}{|c|c|c|c|c|c|c|c|}
\hline \multirow[b]{3}{*}{$\begin{array}{l}\text { Mother cell } \\
\text { morphology }\end{array}$} & \multirow[b]{3}{*}{$\begin{array}{l}\text { Expt } \\
\text { no.* }\end{array}$} & \multirow{2}{*}{\multicolumn{2}{|c|}{ Mother cell }} & \multicolumn{4}{|c|}{ Mean ratios of paired sibs $\dagger$} \\
\hline & & & & \multicolumn{2}{|c|}{ Length } & \multicolumn{2}{|c|}{ Volume } \\
\hline & & $\begin{array}{c}\text { Mean } \\
\text { length }(\mu \mathrm{m})\end{array}$ & & Lo/Sh & PL/SL & $\mathrm{Bi} / \mathrm{Sm}$ & $\mathrm{PV} / \mathrm{SV}$ \\
\hline RBF-like & $\begin{array}{l}\text { I } \\
\text { II }\end{array}$ & $17.8( \pm 3.8)$ & $311 \pm$ & $\begin{array}{l}1.25( \pm 0.19) \\
1.20( \pm 0.19)\end{array}$ & $\begin{array}{l}0.85( \pm 0.16) \\
0.90( \pm 0.16)\end{array}$ & $\begin{array}{l}1.94( \pm 0.45) \\
1.93( \pm 0.45)\end{array}$ & $\begin{array}{l}1.94( \pm 0.45) \\
1.93( \pm 0.45)\end{array}$ \\
\hline $\begin{array}{l}\text { Spheroidal } \\
\text { (RBF progeny) }\end{array}$ & $\begin{array}{l}\text { I } \\
\text { II }\end{array}$ & $11 \cdot 2( \pm 2 \cdot 2)$ & $283( \pm 68)$ & $\begin{array}{l}1.15( \pm 0.13) \\
1.13( \pm 0.11)\end{array}$ & $1.01 \overline{( \pm 0.15)}$ & $\begin{array}{l}1.69( \pm 0.59) \\
1.70( \pm 0.58)\end{array}$ & $0.68 \overline{( \pm 0.25)}$ \\
\hline $\begin{array}{l}\text { Cylindrical } \\
\text { (RBF progeny) }\end{array}$ & $\begin{array}{l}\text { I } \\
\text { II }\end{array}$ & $\begin{array}{c}15 \cdot 3( \pm 2 \cdot 0) \\
-\end{array}$ & $142( \pm 35)$ & $\begin{array}{l}1.09( \pm 0.09) \\
1.11( \pm 0.10)\end{array}$ & $1.06( \pm 0.12)$ & $\begin{array}{l}1.16( \pm 0.15) \\
1.23( \pm 0.17)\end{array}$ & $1 \cdot 11 \overline{( \pm 0 \cdot 24)}$ \\
\hline $\begin{array}{l}\text { Cylindrical } \\
\text { (control) }\end{array}$ & $\begin{array}{l}\text { I } \\
\text { II }\end{array}$ & $24 \cdot 3( \pm 3 \cdot 0)$ & $300( \pm 73)$ & $\begin{array}{l}1.07( \pm 0.06) \\
1.08( \pm 0.08)\end{array}$ & $0.95 \overline{( \pm 0.08)}$ & $\begin{array}{l}1 \cdot 10( \pm 0.09) \\
1 \cdot 11( \pm 0.13)\end{array}$ & $1.00 \overline{( \pm 0.13)}$ \\
\hline $\begin{array}{c}\text { Cylindrical } \\
\text { (normal) } \ddagger\end{array}$ & II & $13 \cdot 9( \pm 1.0)$ & $142( \pm 22)$ & $1.06( \pm 0.04)$ & $1.03( \pm 0.07)$ & $1.07( \pm 0.06)$ & $1.00( \pm 0.09)$ \\
\hline
\end{tabular}

* I, Bright-field microscopy; II, fluorescence microscopy.

$\dagger \mathrm{Lo} / \mathrm{Sh}$, length of long sib/length of short sib; PL/SL, length of primary-pole sib/length of secondary-pole sib; $\mathrm{Bi} / \mathrm{Sm}$, volume of big sib/volume of small sib; $\mathrm{PV} / \mathrm{SV}$, volume of primary-pole sib/volume of secondary-pole sib. $\ddagger$ Mid-exponential phase cells cultured for $16 \mathrm{~h}$ at $25^{\circ} \mathrm{C}$ were used.

cells, $(d)$ spheroidal progeny of RBF-like cells, and (e) RBF-like cells. The magnitude of increase of volume ratios was larger than that of length ratios. The septum position of cylindrical normal cells showed only small asymmetry in both length (1.06) and volume $(1.07)$ parameters: that of the cylindrical control cells also showed small asymmetry (1.07-1.08 in length and $1 \cdot 10-1 \cdot 11$ in 


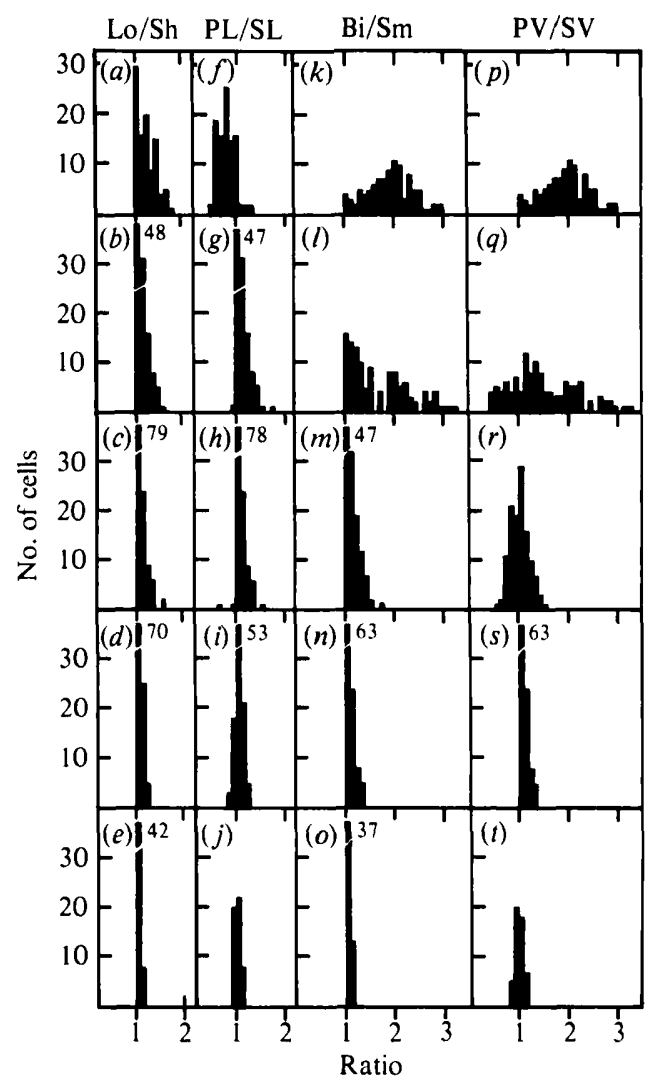

Fig. 5. Distributions of various ratios used for the calculations of the mean ratios in Table 1. The first column from the left $(a, b, c, d$ and $e$ ) shows Lo/Sh ratio, the second column $(f, g, h, i$ and $j)$ PL/SL ratio, the third column $(k, l, m, n$ and $o) \mathrm{Bi} / \mathrm{Sm}$ ratio, and the fourth column $(p, q, r, s$ and $t) \mathrm{PV} / \mathrm{SV}$ ratio. The first step from the bottom $(e, j, o$ and $t$ ) shows ratios of cylindrical normal (mid-exponential phase) cells, the second $(d, i, n$ and $s)$ cylindrical control cells, the third $(c, h, m$ and $r$ ) cylindrical progeny of RBF-like cells, the fourth $(b, g, l$ and $q)$ spheroidal progeny of RBF-like cells, and the fifth $(a, f, k$ and $p)$ RBF-like cells. All ratios are from expt I except those of the cylindrical normal cells (expt II).

volume parameter). In both forms of cylindrical cells ratios of both length and volume were distributed over a narrow range (Fig. $5 d, e, n$ and $o$ ). In contrast the mean volume ratios of the paired sibs of divided RBF-like cells were 1.93-1.94, considerably larger than the mean length ratios $(1 \cdot 20-1 \cdot 25)$ even though the length ratios were distributed over a wide range, $1 \cdot 20-3.00$. The big sib was spheroidal and the small sib was cylindrical without exception (Fig. 2; Fig. $3 a$, $e$; Table 1). Thus the volume of the spheroidal sib was about twice that of the cylindrical sib, a great disparity. At the second division, the mean volume ratios of the paired sibs of the spheroidal progeny of the RBF-like cells were $1.69-1 \cdot 70$, larger than the $1.13-1.15$ mean length ratios even though the length ratios were distributed over the wider range of 0.6 to 3.6 . This disparity of volume and length ratios was also great but less than that of the RBF-like cells. We also noted that the length asymmetry of the cylindrical normal cell was somewhat less than that reported earlier (1.1) in strain NCYC 132 (Johnson et al., 1979), a difference we ascribe directly to the strain differences.

To examine whether the asymmetries were related to the growth pole, that is, whether the septum positions are biased towards the primary or secondary pole (Johnson, 1965; Streiblová \& Wolf, 1972; Johnson et al., 1979), the length (L) and volume (V) ratios of primary-pole sib (P) and secondary-pole sib (S) were calculated (Table 1). Where PL/SL or PV/SV exceeded $1 \cdot 00$, the site of the septum was biased towards the secondary pole, i.e. the primary-pole sib was longer or larger than the secondary-pole sib. 
Table 2. Percentage bias in length and volume of progeny of various morphological classes of cells (calculated from data in Table I)

The method for calculation of the percentage is described in the text. The letters in parentheses show which sib is the longer or bigger. Abbreviations as in Table 1. Results are means of $50-120$ cells.

\begin{tabular}{|c|c|c|c|c|}
\hline \multirow[b]{3}{*}{ Cell morphology } & \multicolumn{4}{|c|}{ Percentage bias } \\
\hline & \multicolumn{2}{|c|}{ Length } & \multicolumn{2}{|c|}{ Volume } \\
\hline & $\mathrm{Lo} / \mathrm{Sh}$ & $\mathrm{PL} / \mathrm{SL}$ & $\mathrm{Bi} / \mathrm{Sm}$ & $\mathrm{PV} / \mathrm{SV}$ \\
\hline RBF-like & 9 & $6(\mathrm{P}<\mathrm{S})$ & 30 & $30(P>S)$ \\
\hline Spheroidal (RBF progeny) & 7 & $<0.5(\mathrm{P}=\mathrm{S})$ & 23 & $20(\mathrm{P}<\mathrm{S})$ \\
\hline Cylindrical (RBF progeny) & 5 & $3(P>S)$ & 9 & $5(P>S)$ \\
\hline Cylindrical (control) & 4 & $3(\mathrm{P}<\mathrm{S})$ & 5 & $<0.5(P=S)$ \\
\hline Cylindrical (normal) & 3 & $1(P \geqq S)$ & 3 & $<0.5(P=S)$ \\
\hline
\end{tabular}

In RBF-like cells, which without exception gave rise to spheroidal primary-pole sibs and cylindrical secondary-pole sibs (Fig. $3 e$ ), the septum positions were biased toward the primary pole by length parameters but towards the secondary pole by volume parameters. Conversely, although the asymmetric sites of the septum in spheroidal progeny of RBF-like cells were biased toward the primary pole by volume parameters, they were not related to the poles by length parameters. On the other hand, the asymmetric sites in cylindrical control and normal cells were hardly related to the poles. From these findings we conclude that there is no simple rule for the bias in these asymmetrically positioned septa.

As the ratios of (the differences between) paired sibs are apt to appear large, we attempted to adopt a concept of the bias from an ideal middle site (TL/2; TV/2) by length or volume parameters about those asymmetrical paired sibs. Percentage bias from an ideal middle site was calculated (Table 2) as $100\{\mathrm{Lo} /(\mathrm{TL} / 2)-1\}$ or $100\{\mathrm{Bi} /(\mathrm{TV} / 2)-1\}$ where Lo is the length of long sib, $\mathrm{TL}$ is the sum of lengths (total length) of long and short sibs, $\mathrm{Bi}$ is the volume of big sib and TV is the sum of volumes (total volume) of big and small sibs. Percentage bias from the ideal middle site of cylindrical control and of normal cells was less than $5 \%$ by either length or volume parameters. This represents a very small bias. In every morphology class there was less than $10 \%$ bias by a length parameter. However, the septum positions of RBF-like and spheroidal cells showed great volume percentage biases from their ideal middle sites.

\section{DISCUSSION}

Exposure of fission yeast cells to sub-lethal concentrations of Acu causes chemical changes in the walls, resulting in gross morphological changes - the formation of RBF-like cells. In spite of these gross changes in morphology, the mean cell volume of RBF-like cells equals that of the controls. Volume equality suggests that the given concentration of Acu did not influence cytoplasmic growth and that the new bulbous shape merely reflects the easiest way for the growing wall to accommodate the expanding protoplast (Miyata et al., 1985). Although cell shape is a character deemed to have very high taxonomic significance, conservation of shape is a luxury readily abandoned by the cells when cell-wall growth is perturbed.

However, cell morphology influenced septum positioning; the more the morphology deviated from the cylindrical form, the greater was the degree of asymmetry. Vraná $(1983 a, b)$ has described conditions of nutrient limitation that can induce length and volume asymmetry at division. For comparison, we calculated the volume ratios of $\mathrm{Bi} / \mathrm{Sm}$ from her data (Table 1 in Vraná, $1983 b$ ) and found the following: the ratio of ovoid cells grown at the lowest dilution rate was $1 \cdot 40$, which lies between the cylindrical and spheroidal progenies of RBF-like cells in our Table 1 with respect to both degree of asymmetry and cell morphology; that of slender cells grown at the fast dilution rate was $1 \cdot 05$, which agrees with our value for cylindrical normal cells. We conclude that it is cell morphology however generated that directly influences septum positioning at cell division. 
Earlier reports on asymmetric septation (Johnson et al., 1979; Vraná, 1983a, b) did not speculate on how the cell establishes the site for an impending division. Nasmyth \& Nurse (1981) and Nurse \& Fantes (1981) observed that cells of $S$. pombe (cdc 13.117) blocked in the middle of mitosis, with apparently condensed chromosomes, initiated septation and that the septa cut across the dividing nuclei (unfortunately they did not illustrate this). They suggested that the location of septation is determined by the position of the dividing nucleus. We noted above (and Miyata et al., 1985) that the nucleus was usually seen at the boundary between the spheroidal and the cylindrical portions of RBF-like cells (at the beginning of the recovery growth). The septum was subsequently found at the same boundary. Even when the interphase nucleus sometimes moved into the bulbous region later in the cell cycle, the septum of the cell was formed at the boundary [unpublished time-lapse photomicrographs of cells growing in gelatin according to Robinow (1975)]. By association, we suggest that the site of the nucleus just before mitosis determined the site of the septum after mitosis.

It is less easy to decide what physiological circumstance determines the site of the nucleus. Of course, its site is not constant but it seems usually to be near the 'middle' of the cell except in immediately post-mitotic cells (McCully \& Robinow, 1971). The observation that division of cylindrical cells generated sibs having approximately equal volumes (Table 1; Johnson et al., 1979; Vraná, 1983a,b) suggests that the nucleus normally finds the middle by measuring some colligative property of the cytoplasm. Perhaps this is the general rule, but there are circumstances in which the volumes of the sibs are disparate. It would seem that the nucleus places itself as near as possible to the middle of these cells, but that proximity to cylindrical wall is a compromising parameter when the middle is bulbous. On the other hand, perhaps the cytoplasm in the bulb is somehow less dense than in the older cylindrical portion, and indeed, the nucleus is finding the 'colligative middle'.

The eventual site of the septum, though possibly predetermined by the nucleus locus, is not rigidly predetermined by the geometry of the cell. The wide range of Lo/Sh ratios for paired sibs of cells of a given length in Table 1, in Johnson et al. (1979), and in Vraná (1983a,b) suggests considerable tolerance in approximating the site.

One studies cells with altered morphology with the hope of learning something new about the morphogenetic capacities of the cell. If, ultimately, a cell's shape is dictated by its genes, one wishes to know what rules are established by the genome and, especially, how those rules are established or enforced; what rules for morphogenesis persist even in cells with altered morphology; what new rules apply in cells with altered morphology; and how the rules apply to the return to normal morphology when the perturbation is removed. These studies on the morphogenetic effects of Acu have given considerable insight into the rules for morphogenesis of fission yeasts.

We thank Masaki Tsunemi for helping to measure cell size, the Research Laboratories of Toyo Jozo, Shizuoka, Japan, for a gift of aculeacin A, and F. G. Villaume of American Cyanamid for a gift of the fluorochrome Calcofluor White M2R New.

This is NRCC publication no. 25257.

\section{REFERENCES}

Hartwell, L. H. (1970). Periodic density fluctuation during the yeast cell cycle and the selection of synchronous cultures. Journal of Bacteriology 104, 1280-1285.

JoHNSON, B. F. (1965). Autoradiographic analysis of regional cell wall growth of yeasts: Schizosaccharomyces pombe. Experimental Cell Research 39, 613624.

Johnson, B. F., Calleja, G. B., Boisclair, I. \& Yoo, B. Y. (1979). Cell division in yeasts. III. The biased, asymmetric location of the septum in the fission yeast cell, Schizosaccharomyces pombe. Experimental Cell Research 123, 253-259.
McCully, E. K. \& Robinow, C. F. (1971). Mitosis in the fission yeast Schizosaccharomyces pombe: a comparative study with light and electron microscopy. Journal of Cell Science 9, 475-507.

Mitchison, J. M. (1970). Physiological and cytological methods for Schizosaccharomyces pombe. Methods in Cell Physiology 4, 131-165.

Miyata, M. \& Miyata, H. (1978). Relationship between extracellular enzymes and cell growth during the cell cycle of the fission yeast Schizosaccharomyces pombe: acid phosphatase. Journal of Bacteriology 136, 558-564.

Miyata, M., Kitamura, J. \& Miyata, H. (1980). Lysis 
of growing fission-yeast cells induced by aculeacin $A$, a new antifungal antibiotic. Archives of Microbiology 127, 11-16.

Miyata, M., Kanbe, T. \& Tanaka, K. (1985). Morphological alterations of the fission yeast Schizosaccharomyces pombe in the presence of aculeacin A: spherical wall formation. Journal of General Microbiology 131, 611-621.

Mizoouchi, J., Saito, T., Mizuno, K. \& Hayano, K. (1977). On the mode of action of a new antifungal antibiotic, aculeacin $A$ : inhibition of cell wall synthesis in Saccharomyces cerevisiae. Journal of Antibiotics 30, 308-313.

Mizuno, K., Yagl, A., Satol, S., Takada, M., Hayashi, M., Asano, K. \& Matsuda, T. (1977). Studies on aculeacin. I. Isolation and characterization of aculeacin A. Journal of Antibiotics 30, 297302.

NASMYTH, K. \& Nurse, P. (1981). Cell division cycle mutants altered in DNA replication and mitosis in the fission yeast Schizosaccharomyces pombe. Molecular and General Genetics 182, 119-124.

NURSE, P. \& FANTES, P. A. (1981). Cell cycle controls in fission yeast: a genetic analysis. In The Cell Cycle, pp. 85-98. Edited by P. C. L. John. Cambridge, London, New York, New Rochelle, Melbourne \& Sydney: Cambridge University Press.

Nurse, P., ThuriauX, P. \& Nasmyth, K. (1976). Genetic control of the cell division cycle in the fission yeast Schizosaccharomyces pombe. Molecular and General Genetics 146, 167-178.

RoBINOw, C. F. (1975). The preparation of yeasts for light microscopy. Methods in Cell Biology 11, 1-22.

Streiblovi, E. \& Wolf, A. (1972). Cell wall growth during the cell cycle of Schizosaccharomyces pombe. Zeitschrift fur allgemeine Mikrobiologie 12, 673-684.

VRANÁ, D. (1983a). The fission yeast Schizosaccharomyces pombe in continuous culture. Biotechnology and Bioengineering 25, 1989-1994.

VRANA, D. (1983b). Morphological properties of Schizosaccharomyces pombe. Folia microbiologia (Praha) 28, 414-419.

Yamaguch, H., HiRatani, T., Iwata, K. \& YamaMoto, Y. (1982). Studies on the mechanism of antifungal action of aculeacin A. Journal of Antibintics 35, 210-219. 